the United States of using incapacitating gases for domestic riot control is another serious snag. Here again, however, there is no reason why even the major powers should not accept a certain degree of fuzziness in what might be required of fellow signatories. It is not as if a violation of whatever treaty there might be would give the violator a decisive advantage.

So what are the prospects that a treaty will eventually be negotiated? And to what extent will the course of events be influenced by the willingness of the House of Representatives to let the Department of Defense have its pilot plant? Given that the Soviet Union (but also France) has the means of using chemical weapons tactically, and on the assumption that, even if the American pilot plant were followed by a full-scale production plant, the munitions produced would be similarly earmarked, there is no reason why the talks at Geneva should be interrupted. Indeed, the new development may persuade the Soviet Union that it would be prudent to make faster progress.
And there is little doubt that, if they chose to do so, the major powers could agree on the text of a treaty that would satisfy their own interests. They have learned, in the past several years, that it is possible to live with measures of arms control whose terms are not as specific as meticulous lawyers would ask. So the prospects for the treaty must depend on whether (and if so when) the major powers decide that the time has come to edge back towards detente. Many will hope that they take the plunge sooner rather than later. When that time comes, they will encounter one of the other longstanding problems of arms control - the unwillingness of other states to sign on somebody else's dotted line. On chemical weapons, France and China at least are likely to insist on their freedom to do what they do at present. Especially now that France has rejoined the enlarged Committee on Disarmament, has not the time come when the major powers should surrender the initiative to the committee? No harm, but only good, could come of such a step.

\title{
Two views on technological change
}

How will new technology affect the structure of society? Off and on, for the past few decades, people have been brooding on this kind of issue. This week, it became known that the British Labour Party is cautiously on the side of the pessimists. An unpublished report due to be considered by the party's National Executive later in the month correctly concludes that recent development in the technology of microprocessors will mean even more unemployment in the United Kingdom unless economic growth keeps pace with increases of productivity now foreseen; predictably, it goes on to argue that increased state intervention in the management of technical and social change is needed. This view neatly follows the publication by the OECD of a report called "Science and Technology in the new socio-economic context" prepared by what the OECD calls a "Group of Experts" for the longstanding Committee for Scientific and Technological Policy (see page 98 ). The OECD document comes to the same conclusion as the Labour Party, but if anything its prescription is more a charter for interference by social scientists than by governments.

During the past three years, there has been a more or less constant grumble that the applications of microprocessors now in prospect have serious consequences for people's jobs. Some will change in character. Some will disappear altogether. These calculations are correct, although the timing is as ever unsure. It does not follow, however, that microprocessors mean mass unemployment. With this as with any technological innovation, improved productivity in one important sector of industry will mean increased wealth, increased demand for goods and services and therefore more jobs in other sectors. The steam engine, whatever the Luddites said and did about it, was as dramatic a source of increased productivity as ever microprocessors will be - and the end result, at least in countries where steam engines were allowed to make a mark, was more jobs. The only reason not to welcome the coming of the microprocessors is that in some places the potential benefits of their increased productivity will not materialize, or will not be matched by comparable increases of productivity stemming from other new technologies.

The Labour Party document, to its credit, has the wit to recognize that this must be the case. The issue that will be disputed is whether more government intervention is the best way of safeguarding the future of jobs in Britain. The dispute is partly ideological. The Labour Party believes in government intervention. The present government does not. Since neither has a monopoly of wisdom, the need is to decide what governments can and cannot do. Providing every classroom or at least each school with a microcomputer might provide a sporting chance that people leaving school were familiar with one new technology, but is this the wisest course when the state school system is crying out for funds with which to buy books, mathematics text-books among them? Equally, the Department of Industry's scheme for helping industrialists become familiar with the new technology, useful though it may be to some of the participants, is no substitute for investors' sense that they can profitably invest in the British economy, and industrialists' sense that the taxation system will allow them to keep some of the profits. In short, what governments can do is to manage the climate for innovation. Governments themselves are less good at innovation. (This is no excuse for the continued delay in deciding whether in Britain the Department of Industry is to let the microprocessor company INMOS have its second $£ 25$ million; the government has a moral obligation that will not go away with the passage of time.)

Broadly speaking, these are the conclusions of the OECD report. The committee marshals impressive evidence which gives the lie to the cynical view that research and development is irrelevant to industrial innovation. The correlation between industrial (as distinct from government) spending on research and development and eventual prosperity is strong. But which is the chicken and which the egg? The OECD committee, while recognizing the difficulty, puts the issue beyond doubt. Governments wishing to foster innovation must foster research and development by industry, but without falling back on shortterm fiscal incentives. It is a hard and self-denying recipe, that would entail in Britain some attenuation of the government's own research enterprise. Yet the case for doing more, not less, when times are hard is undeniable.

On the reasons for the hiatus in the affairs of the industrialized countries in the past seven years, the OECD is nothing if not robust. When money is being drained out of the economy, largely by OPEC, cannot be the best time for innovation or even mere change. All that is easier when things are going well. Yet this is a turning point in many people's affairs. More productivity is in the long run the only way out of the crisis. Although the report is short on references to the economists' gurus, Keynes and Friedman alike, it leaves the clear impression that the committee that prepared it considered that innovation is not so much a problem as an answer to an unstated problem. The committee's dissident voice, Professor Emma Rothschild, found this escalator uncomfortable because she had no clear idea where it is going. That is too much to ask.

That is the sensible part of the OECD report. It is less sensible that much of the document is taken up with the supposed need of what is fashionably called technological forecasting. This, after all, is a discipline which has yet to demonstrate itself as such. Many will suspect the phrase to be yet another licence for social scientists to make contradictory assertions about the consequences of technological innovations. The trouble, of course, is that the consequences are almost always unpredictable. All that can confidently be said is that some consequences are profound. What societies faced with rapid technological change thus need of their governments is flexibility - a capacity (and a willingness) to meet unforeseen social changes with compassion and imagination. 